\title{
Medical Tourism:-A New Paradigm Shift in the Recent Times a Special Reference with Medigo Gmbh India

\author{
Molly Chaturvedi, M. Kishore Babu,
}

\begin{abstract}
The process of medical tourism is defined as the various steps involved in the facilitation of medical treatment for the overseas patients. This process stretches from point of first contact or initial patient acquisition to follow up treatment and consultation on completion of a treatment plan. The medical tourism process comprises of the various stages of travelling for medical and healthcare-based activities that are all handled by a good and reliable medical tourism facilitator. The study aims and intends to comprehend what precisely do patients need to do to get treatment in nations with a less expensive and subjective therapeutic framework and whether restorative visitor organizations or facilitators are assuming a colossal job in this procedure or that there may be sure zones in which they may need to improve whether it be in the presentation of new innovation based systems or in the visa and travel record application process or in certain different regions where patients need help with request to be treated in the most ideal way. The study is undertaken by collecting the primary data of medical tourists/patients destined for treatment in India for a period of 1 year (2016-2017).
\end{abstract}

Keyswords: Medical Tourism National Borders, Patients, Travelling, Tourism facilitator.

\section{INTRODUCTION}

Therapeutically Medical Tourism can be defined as, individuals going abroad, to acquire various rejuvenations or treatments. Previously, this normally indicated to the individuals who went from developing nations to significant medicinal availabilities in most well-developed nations for treatment inaccessible at locally. Medicinal-Travel industry began its history, during early 20th century in 1930's. It was most prevalent among US and quite a lot of European nation's wealthy and famous people, who needed to get great quality wellbeing administrations abroad. Since 1983, being fit and aware of healthy lifestyle has been buyers' top need and, as indicated by the Future Foundation's Changing Lives Survey, this trend will keep on being a trend later, travelling abroad for medical advantages is certainly not an ongoing idea, it has been increasing more focus and media enthusiasm for the most recent decades. This insistent influences along with the dependability and likeness of information, nature of distributed research, reports, measurements and articles have been profound. There have regularly been some endeavours to characterize this industry.

Revised Manuscript Received on November 15, 2019.

* Correspondence Author

Molly Chaturvedi*, Management department, K.L. University, Vijayawada, India. Email: chaturvedi.molly@gmail.org

Dr. M. Kishore Babu, Director, International Relations, KL University, Vijayawada, Andhra Pradesh, India. Email: kishore@kluniversity.in

(C) The Authors. Published by Blue Eyes Intelligence Engineering and Sciences Publication (BEIESP). This is an open access article under the CC BY-NC-ND license (http://creativecommons.org/licenses/by-nc-nd/4.0/)
At the point when buyers choose to make a trip across the globe to get some type of therapeutic treatment, which may traverse the full scope of medicinal administrations (most usually incorporates dental consideration, corrective medical procedure, elective medical procedure and various types of treatment). Defining the limit of what is wellbeing and considered restorative treatment, the travel industry for the reasons of records isn't quite clear. Inside this scope of treatment, not all may included the wellbeing part. Corrective medical procedure for esthetical as opposed to reconstructive reasons, for instance, would be considered outside the wellbeing bounds. Segen's Medical Dictionary, 2012 "There are three categories of medical tourism: outbound, inbound, and intra-bound (Term coined by travel agencies and the mass media for the practice of travelling across national borders to obtain health care". It also refers to the practice of healthcare providers travelling internationally to deliver healthcare, which is both pejorative and less common) . According to the Confederation of Indian Industries (CII), India is unique as it offers holistic medicinal services. With yoga, meditation, Ayurveda, allopathy, and other systems of medicines, India offers a unique basket of services to any individual that is difficult to match by most countries, says CII. Also, clinical outcomes in India are at par with the world's best centers, besides having internationally qualified and experienced specialists. Statistics suggest that the medical tourism industry in India is worth \$333 million (Rs 1,450 Crore) while a study by CII-McKinsey estimates that the country could earn Rs 5,000-10,000 Crore by 2012. The study predicts that, "by 2012, if medical tourism were to reach 25 per cent of revenues of private up-market players, up to Rs 10,000 Crore will be added to the revenues of these players". According to the Government of India recent report. "India's \$17-billion-a-year health-care industry could grow 13 per cent in each of the next six years, boosted by medical tourism, which industry watchers say, is growing at 30 per cent annually. Probably realizing the potential, major corporate such as the Tata, Fortis, Max, Wockhardt, Piramal, and the Escorts group have made significant investments in setting up modern hospitals in major cities". Many have likewise structured extraordinary bundles for patients, including air terminal pickups, visa help and board and hotel stay etc. The medical services segment in India has seen a tremendous development in its framework in the private sector. The private agencies, which was low profile in the beginning, has now turned into a prospering industry outfitted with the most present day, best in class innovation that are available.

Published By:

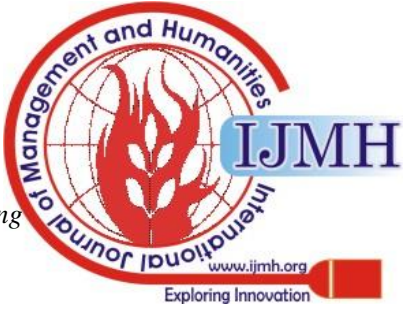


It is assessed that $75-80 \%$ of human/well being services administrations and interests in India are presently given by the private division. An additional advantage had been that India has one of the biggest pharmaceutical businesses on the planet. It is self-reliant in medication formulation/API creation and exports medications to in-excess of 180 nations. India has first rate units for open-heart medical procedure,

paediatric heart medical procedure, hip and knee replacement/restoration, restorative dermatology medical procedure, dentistry, bone marrow transplants and various ailment's treatment, and practically the majority of India's centre's are furnished with the most recently procured electronic equipment and medicinal devices. In contrast to a significant number of its rivals in medicinal the travel industry, India likewise has the innovative modernity and foundation to keep up its market specialty, and Indian pharmaceuticals meet the stringent prerequisites of the U.S. Nourishment and Drug Administration. Furthermore, India's medical standards matches up to American norms, and some Indian therapeutic units even give benefits that are extraordinary in nature. For instance, hip medical procedure patients in India can decide on a hip-re-emerging technique, in which harmed bone is scratched away and supplanted with chrome combination - an activity that costs less and causes less post-procedural issues than the customary procedures performed in the most developed medical centre's in U.S, while a quite a few private hospitals in India are open to extending medicinal procedure to a lot of patients, without cognizance of their nationality, only a few are in the forefront of promoting the health-hospitality mix. Some of the major hospitals in the country that have been in the forefront of medicinal uprising are:

- $\quad$ Escorts H.I. \& R. C. Unit

- Apollo Group

- Wockhardt Chain

- Fortis Healthcare

- Manipal Center

- $\quad$ PD Hinduja N. H. \& M.R.C.

- Tata Memorial Cancer Hospital

Apart from the private players, public sector hospitals like All India Institute of Medical

Sciences (AIIMS) has been receiving patients from over 16 countries including European nations and there is a steady increase in the number of patients, mainly for complex surgical procedures. The AIIMS has also initiated a dedicated International Healthcare Service team, which will take care of the patient right from arrival till their departure coordinating all aspects of medical treatment. When individuals who live in one nation travel to another nation to receive restorative treatment, dental procedures, while simultaneously expecting equivalent or more significantly better treatment than they would have in their own nation, and are going for medicinal consideration due to economic moderateness, better access or a more significant level of nature of medicinal consideration. "Domestic Medical Tourism" is the place individuals of the same nation travel to another city, area or state to get therapeutic, dental procedures, while simultaneously getting equivalent or more prominent consideration than they would have in their very own home town, and are going for restorative consideration on account of reasonableness, better access to mind or a more elevated level of nature of medicinal consideration". Factors which have assumed a huge importance in the medicinal Travel industry is expanding ubiquity of therapeutic travel incorporate, significantly expensive specific systems, the simplicity and moderateness of worldwide travel, and upgrades in both innovation and norms of consideration in numerous nations. An authority at the Harvard Business School states that "medical tourism is promoted much more heavily in the United Kingdom than in the United States". Popular medical travel worldwide destinations include India, Canada, Costa Rica, Ecuador, Israel, Jordan, Malaysia, Mexico, Singapore, Taiwan, South Korea and Turkey.

\section{OBJECTIVES OF THE STUDY}

1. To study the process of medical tourism as adopted by Medigo GMBH.

2. To study the flaws and aberrations in the existing process of medical tourism.

3. To study the various technological tools and devices in vogue currently by Medigo for facilitation of the medical tourist process.

4. To offer suggestions and recommendations based on the study.

\section{MODEL OF MEDICAL TOURISM}

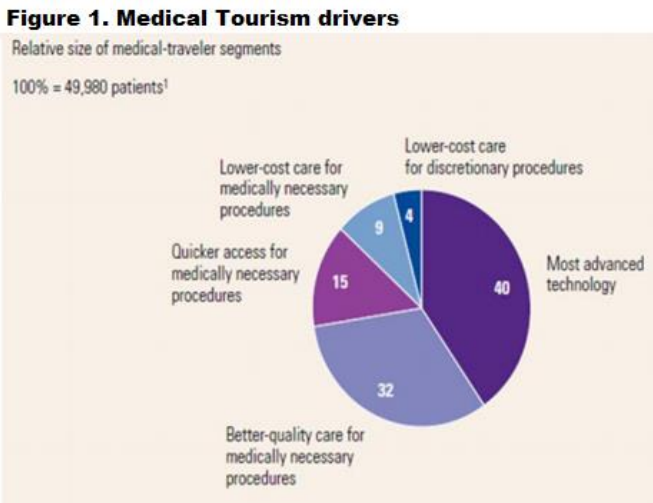

Number of patients come from
represent $60-80 \%$ of market.

Source: Intervicws with providers and patient-level data; McKinsey analysis

5ource: McKinsey Quarterly, Mapping the market for medical travel, 2008

As per K. Pollard's "model of destination attractiveness". which doesn't involves machinery and superiority assessment and involves seven major factors.

- The Geological nearness, journey period, convenience in getting to the objective.

- The edifying nearness having verbal communication, faith, belief, eating habits and traditions. Acquaintance and likeness, play an important role.

- The Repute of the nation and typecast, are difficult to turn round. Which have a great impact on the patient's views of a medical procedure.

- The Overall network of a Nation and/or cure resources.

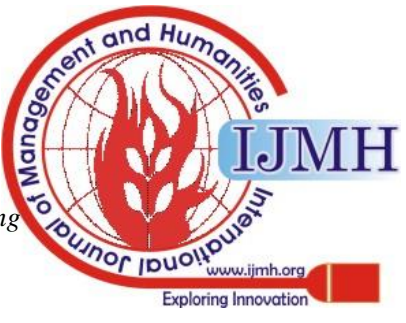


- The surroundings and environment, basic desirability, amenities and aspect that have the more pull to get the procedures done.

- Mitigation of possible threats. Medicinal traveller may bearing in mind security, cure assurance, previous accounts of meticulous medicinal services to the purposed nation etc.

- Cost. Procedure's price is important, and travelling, stay and relevance of insurance.

\section{RESEARCH METHODOLOGY}

\section{A. RESEARCH DESIGN}

The Research was "Exploratory" in nature as the study aims to examine and explore the existing process of medical tourism and to ascertain whether there is any inadequacies and issues with the existing process.

\section{B. SAMPLE DESIGN}

In this study," non-probability-based sampling" was chosen as a medium for carrying the research to its logical conclusion. The sample technique adopted for the purposes of this research was "Convenience sampling".

\section{DATA COLLECTION METHODS}

\section{Primary Data:}

The primary data for this research was collected using a questionnaire which was administered to customers/patients of MEDIGO GMBH who visited India period for the treatment. The project provides a profound and penetrating insight into the actual workings of the medical tourist process as adopted by MEDIGO GMBH. It focuses on whether the process by itself as a positive or negative impact on patient/customer experience. The scope of the study is restricted to MEDIGO GMBH's process and operations for medical tourists/patients destined for treatment in India for a period of 1 year (2016-2017).

\section{Secondary Data:}

Secondary data was collected through various sources like:

- Text Books

- Journals

- Published data

- Web Sources

- Magazines

- Government data

\section{Tools/Techniques}

The data was collected through structured questionnaire. The questions were framed using

Likert Rating scale method.

\section{Sample size}

The size of the sample considered for the purpose of this research is " 50 ".

\section{DATA ANALYSIS AND INTERPRETATION}

1. Gender Of The Respondents.

\begin{tabular}{|c|c|c|}
\hline Gender & No of respondents & Percentage \\
\hline Male & 39 & $76.5 \%$ \\
\hline Female & 11 & $23.5 \%$ \\
\hline
\end{tabular}

Data Analysis \& Interpretation
The above Table and chart depicts that 39 Respondents are male and 11 respondents are female. The above table and chart shows that $76.5 \%$ of the respondents to this survey are male and $23.5 \%$ of respondents to this survey are female. So male respondents are more highly represented in this survey than female respondents

2. Age of The Respondents.
\begin{tabular}{|c|c|c|}
\hline Age & No of respondents & Percentage \\
\hline Less than 20 & 01 & $02 \%$ \\
\hline $21-40$ & 19 & $37.3 \%$ \\
\hline $41-60$ & 30 & $60.8 \%$ \\
\hline Above 60 & 0 & 0 \\
\hline
\end{tabular}

\section{Data Analysis \& Interpretation}

The above table and chart shows that $61 \%$ of the respondents are between the age group of 41-60 years. It also shows that $37 \%$ of respondents are between the age group of $21-40$ years and $2 \%$ are less than 20 years. So a majority of respondents are within the age bracket of 41-60 years.

\section{Nationality of The Respondents}

\begin{tabular}{|c|c|c|}
\hline Nationality & No of Respondents & Percentage \\
\hline GCC (Gulf countries) & 18 & $33 \%$ \\
\hline European countries & 12 & $25 \%$ \\
\hline United States\& Canada & 04 & $8 \%$ \\
\hline Australia \& New Zealand & 03 & $6 \%$ \\
\hline Other & 13 & $28 \%$ \\
\hline
\end{tabular}

Data Analysis \& Interpretation:

The above table and chart depicts that $33 \%$ of the respondents surveyed for the purpose of this research are from GCC or gulf countries, $7 \%$ are from Australia and New Zealand, 6\% are from the United States and Canada, and $29 \%$ of respondents are from other countries not taken into consideration for the purposes of this survey

\section{4 . Medical Issues Faced by The Respondent Necessitating Treatment In India}

\begin{tabular}{|c|c|c|}
\hline Type of ailment & Number of Respondents & Percentage \\
\hline Cancer \& Palliative care & 07 & $13.7 \%$ \\
\hline Cardiovascular diseases & 23 & $45.1 \%$ \\
\hline Neurological Disorders & 10 & $21.6 \%$ \\
\hline $\begin{array}{c}\text { Plastic and reconstructive } \\
\text { treatments }\end{array}$ & 10 & $19.6 \%$ \\
\hline Others & 0 & $0 \%$ \\
\hline
\end{tabular}




\section{Data Analysis \& Interpretation}

From the above table and chart, we can interpret that $45 \%$ of the respondents came for Treatment to India for Cardiovascular diseases, 21\% came for neurological disorder-based treatment and $14 \%$ came for Cancer \& Palliative care treatment. We also understand that $20 \%$ of the respondents came for plastic and other reconstructive based treatments.

\section{5 . Duration Of Stay Of Respondent In India}

\begin{tabular}{|l|l|l|}
\hline Duration of stay & No of respondents & Percentage \\
\hline Less than one month & 10 & $21.6 \%$ \\
\hline Less than 3 months & 34 & $66.7 \%$ \\
\hline Less than 6 months & 06 & $11.8 \%$ \\
\hline Other & 0 & 0 \\
\hline
\end{tabular}

\section{Data Analysis \& Interpretation}

The above table and chart depicts than $67 \%$ of the respondents came to India for a duration of less than 3 months, and $21 \%$ came for a period less than 1 month and finally $12 \%$ came for a period of time which was less than 6 months. The survey interprets that more than $67 \%$ of the respondents came to India for some duration less than 6 months for medical treatment.

\section{6 . Reasons For Respondent's Choice Of Treatment In India}

\begin{tabular}{|l|l|l|}
\hline Reasons & No of Respondents & Percentage \\
\hline $\begin{array}{l}\text { Cheaper cost of } \\
\text { treatment }\end{array}$ & 26 & $51 \%$ \\
\hline $\begin{array}{l}\text { Proximity to home } \\
\text { country }\end{array}$ & 0 & 0 \\
\hline $\begin{array}{l}\text { Qualitative } \\
\text { treatment }\end{array}$ & 20 & $41.20 \%$ \\
\hline $\begin{array}{l}\text { Marketing by } \\
\text { Medigo }\end{array}$ & 4 & $7.80 \%$ \\
\hline
\end{tabular}

\section{Data Analysis \& Interpretation}

The above table and chart shows us that $51 \%$ of the respondents chose India as the destination for their treatment due to its cheaper cost of healthcare, $41 \%$ of respondents chose India because of its comparatively qualitative healthcare system and $8 \%$ chose India because of Medigo's effective marketing campaigns. The survey concludes that $51 \%$ of respondents chose India as their destination of call for their medical treatments and consultations because of its comparatively cheaper cost of healthcare. India's system of healthcare is low cost and high quality.

\section{How Did You Become Aware Of Medigo Gmbh}

\begin{tabular}{|l|l|l|}
\hline Mediums company & 18 & percentage \\
\hline $\begin{array}{l}\text { Through of respondents } \\
\text { website }\end{array}$ & 01 & $37.3 \%$ \\
\hline Through internet articles & 29 & $56.9 \%$ \\
\hline $\begin{array}{l}\text { Through inevious } \\
\text { patient referrals }\end{array}$ & 02 & $3.9 \%$ \\
\hline $\begin{array}{l}\text { Through company-based } \\
\text { advertisements in } \\
\text { various media }\end{array}$ & \\
\hline
\end{tabular}

Data Analysis \& Interpretation
The above table and chart depicts that 57\% of all respondents in this survey became aware ofMedigo GMBH through previous patient referrals. It also shows that $37 \%$ became aware of Medigo GMBH through its company website and 4\% became aware of Medigo through its advertisements on various media. Finally, 2\% became aware of Medigo through various articles published about in the internet. The survey interprets that $57 \%$ of all respondents in this survey became aware of Medigo GMBH due to previous patients/customer-based referrals.

8 . Medigo Customer Team Courteous And Sensitive To Your Requirements As A Customer

\begin{tabular}{|l|l|l|}
\hline Sensitivity to requirements & No of respondents & percentage \\
\hline Strongly agree & 06 & $13.7 \%$ \\
\hline Agree & 34 & $66.7 \%$ \\
\hline Neutral & 10 & $19.6 \%$ \\
\hline Disagree & 0 & 0 \\
\hline Highly disagree & 0 & 0 \\
\hline
\end{tabular}

\section{Data Analysis \& Interpretation}

The above table and chart depict that $67 \%$ of all respondents for the purpose of this survey agree that Medigo's customer service Team was courteous and sensitive to their requirements, $14 \%$ strongly agree with this notion and $19 \%$ are neutral on this notion. From the above survey, we can interpret that $67 \%$ of all respondents agree that Medigo's customer team was sensitive to customer requirements, however we interpret that they did not strongly agree with this notion indicating a deficiency or a perceived inadequacy in their interactions with the Medigo customer team.

9. Drawback With Medigo's Existing Process Of Medical Tourism.

\begin{tabular}{|l|l|l|}
\hline Issues of & Percentage \\
\hline $\begin{array}{l}\text { Lack of a dedicated web } \\
\text { based mobile application for } \\
\text { rustomer to company } \\
\text { interaction }\end{array}$ & 47 & $92.2 \%$ \\
\hline $\begin{array}{l}\text { Unresponsive customer } \\
\text { relationship advisers }\end{array}$ & 02 & $5.9 \%$ \\
\hline $\begin{array}{l}\text { Unprofessional Local Liaison } \\
\text { agents }\end{array}$ & 01 & $2 \%$ \\
\hline Untrained partner doctors & 0 & 0 \\
\hline
\end{tabular}

\section{Data Analysis \& Interpretation}

The above table and chart depicts that $92 \%$ of the total respondents feel that the biggest drawback with Medigo's existing process of Medical tourism is the Lack of a dedicated web based mobile application for customer to company interaction. 6\% feel that customer relationship advisers were unresponsive,finally $2 \%$ felt that the local Liaison agents were unprofessional.From the above survey, we can interpret that the lack of a dedicated web-based application with data controls and privacy authentication for real time status updates and communication during transit is a cause for customer dis- satisfaction with Medigo. 
10 . Medigo Could Have Added A Local Destination Manager Instead Of Relying Solely On A Regional/Zonal Manager For The Smooth Conductance Of The Medical

\section{Tour.}

\begin{tabular}{|c|c|c|}
\hline Opinions & No of respondents & Percentage \\
\hline Strongly agree & 49 & $98 \%$ \\
\hline Agree & 01 & $2 \%$ \\
\hline Neutral & 0 & 0 \\
\hline Disagree & 0 & 0 \\
\hline Strongly Disagree & 0 & 0 \\
\hline
\end{tabular}

\section{Data Analysis \& Interpretation}

The above table and chart shows that $98 \%$ of all respondents strongly agree that Medigo needs to have a local destination manager at each destination for better co-ordination and customer relations. It also shows that $2 \%$ also agree with this notion.From the above survey, we interpret that $98 \%$ of the total respondents strongly agree that instead of overburdening the zonal manager with direct supervision and responsibility, Medigo needs to also hire local destination managers for effective delegation of responsibilities with regards to the day to day co-ordination of medigo's patients in each city.

\section{1 . Feeling Of Security During Your Visit To India.}

\begin{tabular}{|c|c|c|}
\hline Feeling rate & No of respondents & Percentage \\
\hline Strongly agree & 06 & $11.8 \%$ \\
\hline Agree & 38 & $74.5 \%$ \\
\hline Neutral & 06 & $13.7 \%$ \\
\hline Poor & 0 & 0 \\
\hline Very poor & 0 & 0 \\
\hline
\end{tabular}

\section{Data Analysis \& Interpretation}

The above table and chart depicts that $74 \%$ of the total respondents agree that they felt a sense of security during their trip to India. 12\% strongly agree with this notion and $14 \%$ are neutral about their feeling of security.Thus, from the above survey, we can interpret that $74 \%$ of the total respondents agree that they felt a sense of security during their trip to India.

\section{Over-All Experience In India}

\begin{tabular}{|c|c|c|}
\hline Options & No of respondents & Percentage \\
\hline Very good & 08 & $15.7 \%$ \\
\hline Good & 38 & $76.5 \%$ \\
\hline Average & 04 & $7.8 \%$ \\
\hline Poor & 0 & 0 \\
\hline Very poor & 0 & 0 \\
\hline
\end{tabular}

\section{Data Analysis \& Interpretation}

From the above table and chart, we can deduce that $76 \%$ of the total respondents feel that their experience in India was good. $16 \%$ feel that it was very good and $8 \%$ feel that it was average. From the above survey, we can interpret that $76 \%$ of the total respondents feel that their experience in India was good leaving scope for improvements.

\section{SUGGESTIONS \& MANAGERIAL IMPLICATIONS}

$>$ Medigo should engage in more advertising activities in order to encourage more people to engage in medical tourism.

$>$ Medigo should appoint better qualified local liaison officers on a direct company contract instead of outsourcing hiring to third party agencies for better qualitative training, direct supervision and service quality assurance.

> Medigo should sign a MOU with several local and national governments including in India for establishing a Centre of excellence for local training and development.

$>$ Medigo medical programme should also include recreational and sight-seeing activities for better customer satisfaction.

$>$ Medigo should better strive to improve patient security through establishing contacts with diplomatic embassies of each patient for follow- up and reporting.

\section{Limitations}

$>$ The duration of this study was limited

$>$ Since the number of respondents is limited, A thoroughly accurate assessment of Medigo's process of medical tourism is not possible.

$>$ Since the study is based solely on customer viewpoint and has not taken into consideration the company's point of view. The study could be a little customercentric or biased.

$>$ Since the present Medical tourist facilitators in India only specialize in inter- domestic medical tourism which is not a contributory factor towards the working of this research. Their activities are not a point of consideration in this study.

$>$ Even though the medical tourist market in India is slated to be among the fastest growing healthcare-based sectors contributing Forex and FDI. There is still a lack of clarity as to Government regulations governing this sector.

\section{CONCLUSIONS}

$>$ Medigo is a rapidly growing Medical tourist facilitator both in Europe and from a global perspective.

$>$ Medigo has till now relied on social media and webbased marketing to make people aware of its role and services provided.

$>$ There is a huge potential customer base and a rosy future prospect for Medigo GMBH because according to KPMG, it is estimated that the potential value of the medical tourist sector is $\$ 32.5$ billion as per market forecasts for 2019, also 38\% of all people in the world have at any point of time considered traveling abroad for medical reasons and each year 14 million people travel for medical treatment around the world.

$>$ Medigo can explore the hugely untapped but highly qualitative medical infrastructure of India for furtherance of the highly profitable market.

\section{REFERENCES}

1. Bristeir, J. (2016). Medical Tourism. Paris: Wen Publishing

2. Delloite. (2018). Global Health Care Outlook. USA: Delliote Publishing .

3. Frederick.J.Demicco. (2017). Medical Tourism \& Wellness. Florida: Apple academic press.

Published By: 
4. Gupta, R. A. (2008). Medical Tourism:A growth Industry. NewDelhi: ICFAI University Press.

5. Industries, C. o. (2018). Medical Tourism in India . New Delhi: FICCI.

6. J.C.Segen. (1992). The Dictionary of Modern Medicine. USA: CRC Press .

7. Jose Angel Gurria. (2013). Organisation for Economic Co-operation and Development . Paris,France: Organisation for Economic Cooperation and Development .

8. Larson, S. F. (2013). Medical Tourism :India. NewDelhi: First Edition edition

9. M.Bookman. (2007). Medical Tourism in Developing Countries . London: Palgrave Macmillan.

10. Mandal, P. ( 1st ed. 2016 ). Development of Tourism and the Hospitality Industry in Southeast Asia. Mumbai: Springer; 1st ed. 2016 edition (18 December 2015).

11. Page, C. M. (2016). The Routledge Handbook of Tourism in Asia. USA: Routledge; 1 edition.

12. Sharma, G. D. (2011). Medical tourism: on the growth track in India . Mumbai: Grin Publishing.

13. Singh.M. (2012). Medical Tourism . New Delhi: Centrum Press.

14. Stolley, K. M. (2015). The intersection of star culture in America and international Medical tourism. USA: Lexington Books.

15. Vafadri, M. C. (2015). Current issues and emerging trends in Medical Tourism. Newyork: Idea Group.

\section{AUTHOR'S PROFILE}

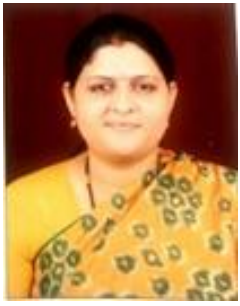

Mrs. Molly Chaturvedi is pursuing $\mathrm{PhD}$ from K L University ,Vijayawada ,completed he masters (MBA) and Bachelor degree (BBA )with marketing as specialization in first division from the Bhopal University. She has qualified APTS -SET in the year 2014 conducted by the Osmania University .She has also acquired the "O" level certificate from the DOEACC society. She has 9 years of teaching experience in handling Marketing ,General Management papers of PG and UG courses .Her major achievements includes being in charge of NAAC Research Criteria (National Accreditation Assessment Council) from her college ,conducted various Guest lectures, Case studies ,Panel Discussions, Field visits,PG \& UG course structure and syllabus revisions,organised Management Development Programme(MDP), Faculty development Programme (FDP),Faculty workshops, in her college . She has authored 17 research papers till date in different National and International conferences and Journals.

Some of her prominent research article includes :-

* Paper Published on "A study of online shopping behavior in retail sector' ISSN 2277-3789, IMPACT FACTOR POWER BY I2OR: 3.010 I2OR, JIF(Bi-annual) in The Journal of global management outlook on Feb 1, 2018.

* Paper published on 'A Study on Challenges and Opportunities of Rural Marketing' in International Journal of current Research, IMPACT FACTOR-7.086, Volume 9 Issue 11,Page no.61682-61686 on Nov 2017.

* Paper published on 'A Conceptual Study on Recent Trends, Challenges and Opportunities in E- Marketing': In Special Reference with 7 Up Case Study at 2nd International Conference on "Global Opportunities \& Challenges in Commerce "(ICGOCC 2018) in Collaboration with International Skill Development Corporation for International Journal of Engineering Technology Science and Research IJETSR, ISSN 2394 - 3386, Nov 2017

* Paper presented was published on 'Building High Team \& its Sustenance in International Journal of Management \& Social science (IJMSS) (ISSN: - 2321-1784) Impact factor: -4.259, Vol.3, Issue3, March 2015.

* Paper presented was published on Micro finance- 'A blessing in disguise to the poor' in INSPIRA NATIONAL JOURNAL ISSN:2231-167X, Volume 05 No. 02, April 2015.

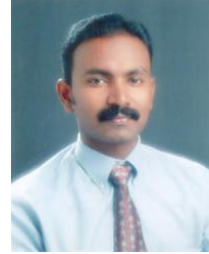

Dr. M. Kishore Babu has 23 years of experience in both Academics \&amp; Industry. He truly believes in teamwork and academic leadership. He served as Head and Principal of the prestigious KLU Business School from 2013 to 2018. Now discharging as Director, International Relations, K. L. University. He got his Ph. D from Acharya Nagarjuna University, M. Phil in 2001 from Andhra University. He published 7 books and Guided $4 \mathrm{M}$. Phil. Scholars and $4 \mathrm{Ph} . \mathrm{D}$. scholars were awarded under his guidance. He has published 72 papers in various reputed international \&amp; national journals: Had organized 92 work-shops independently as a resource person for Corporates, Non-profit organizations, Software Industry, NABARD, and Voluntary organizations, National Banks, RYLA and APSRTC. Have visited many countries to expand K L University horizons globally. He established linkages with 73 universities including Stanford, Harvard universities, to promote academic excellence and global exchange programs. Under his leadership K L Business School ranked 46th among all Business Schools in India including IIMs, IITs, and NITs as per NIRF rankings of MHRD, Govt. of India. $\mathrm{He}$ is instrumental in establishing many collaborations with Industries and Universities. His area of expertise is Marketing, Brand Management, and Sales

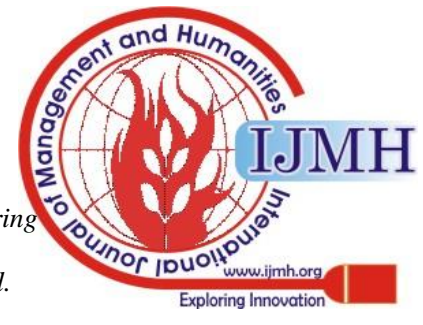

